\title{
Marcin Bogdański
}

Uniwersytet Warmińsko-Mazurski w Olsztynie

\section{DELIMITACJA OBSZARU AGLOMERACJI OLSZTYŃSKIEJ}

Streszczenie: Celem pracy było określenie granic obszaru aglomeracji olsztyńskiej. Aglomeracja ta stanowi silnie zintegrowany funkcjonalnie obszar, w którym realizowane są różnorodne funkcje o charakterze produkcyjnym, konsumpcyjnym, administracyjnym czy handlowym. Mogą być realizowane w różnych fragmentach obszaru aglomeracyjnego, stąd pod tym względem nie jest on jednorodny, ale zawsze charakteryzuje się dużym stopniem integracji, intensywności powiązań. Najważniejszym, choć nie jedynym, kryterium używanym do delimitacji miejskiego regionu funkcjonalnego jest przestrzenny zasięg codziennych dojazdów do pracy.

Przyjęte wskaźniki służące delimitacji obszaru aglomeracji odnosiły się do kryterium morfologicznego (czyli związanego ze stopniem, intensywnością wykorzystania przestrzeni), kryterium funkcjonalnego (odzwierciedlającego stopień powiązań miasta centralnego z otaczającym go obszarem) oraz kryterium dynamiki procesów społeczno-gospodarczych zachodzących na obszarze aglomeracji (odnosiły się one przede wszystkim do dynamiki procesów migracyjnych oraz tempa rozwoju gospodarczego badanych jednostek). Jedną z charakterystycznych cech aglomeracji jest bowiem większa intensywność i zmienność przemian dokonujących się w jej funkcjonowaniu.

Przeprowadzone analizy pozwalają na stwierdzenie, że obszar aglomeracji olsztyńskiej stanowi (oprócz samego Olsztyna) 12 gmin. 9 z nich należy do powiatu olsztyńskiego (Barczewo, Dobre Miasto, Dywity, Gietrzwałd, Jeziorany, Jonkowo, Purda, Stawiguda, Świątki), dwie do powiatu szczycieńskiego (Dźwierzuty, Pasym) oraz jedna do powiatu ostródzkiego (Łukta).

Według danych GUS pod koniec 2010 r. obszar aglomeracji olsztyńskiej zamieszkiwały 268684 osoby, co stanowiło 18,8\% ludności całego województwa. Powierzchnia aglomeracji wynosi z kolei $2682 \mathrm{~km}^{2}$, czyli 11,1\% powierzchni województwa. Na terenie aglomeracji swoją siedzibę mają najwięksi, najważniejsi w województwie warmińsko-mazurskim pracodawcy, instytucje rządowe i samorządowe, uczelnie wyższe. Ponadto w Olsztynie zlokalizowane są ważne instytucje kulturalne, gospodarcze, a także placówki opieki zdrowotnej. W strukturze produkcyjnej aglomeracji dominuje przemysł spożywczy, maszynowy, meblarski oraz oponiarski. Ważną branżą, ze względu na położenie oraz walory krajobrazowe, pozostaje także turystyka.

Można też zauważyć, że o ile w przypadku kryterium powiązań funkcjonalnych oraz dynamiki przebiegu procesów społeczno-gospodarczych można mówić o dość wyrazistych powiązaniach właściwych aglomeracjom miejskim, o tyle względnie słabo zauważalne aspekty związane z wykorzystaniem przestrzeni każą zaliczyć obszar aglomeracji olsztyńskiej do aglomeracji dopiero wyłaniających, kształtujących się.

Słowa kluczowe: aglomeracja miejska, obszar funkcjonalny, Olsztyn.

DOI: $10.15611 / \mathrm{e} 21.2014 .1 .04$ 


\section{Wstęp}

Skuteczne działanie na rzecz podniesienia poziomu rozwoju gospodarczego, poprawy życia mieszkańców, przyciągnięcia inwestorów wymaga, aby władze jednostek terytorialnych miały jasno sprecyzowaną i konsekwentnie realizowaną politykę rozwoju. W przypadku polityki miejskiej rodzi to jednak istotny problem o dużym znaczeniu badawczym i praktycznym. Miasta, pomimo precyzyjnie określonych granic administracyjnych, nie stanowią izolowanych punktów w przestrzeni. Ich zakres oddziaływania na otaczającą przestrzeń jest różny w zależności od liczby mieszkańców, struktury produkcji, stopnia zurbanizowania regionu itd. To oznacza konieczność koordynacji działań inwestycyjnych, infrastrukturalnych, gospodarczych, podejmowanych przez władze ośrodków znajdujących się w strefie wpływów dużego miasta, wchodzących w skład aglomeracji miejskiej. Precyzyjna delimitacja tej strefy pozwala włączyć w proces zarządzania rozwojem aglomeracji nie tylko władze miasta centralnego, ale także decydentów ośrodków położonych wokół niego, co daje możliwość podniesienia jakości życia w aglomeracji oraz przyczynia się do podniesienia poziomu i dynamiki ich rozwoju.

Celem prezentowanych analiz jest wskazanie granic obszaru funkcjonalnego aglomeracji olsztyńskiej. Województwo warmińsko-mazurskie należy do najsłabiej rozwiniętych gospodarczo obszarów Polski. Jednocześnie struktura produkcji, poziom jej technologicznego zaawansowania oraz jakość kapitału ludzkiego nie dają podstaw, aby można było się spodziewać, że region ten w przyszłości będzie mógł osiągnąć wyższą dynamikę rozwoju bez przyciągnięcia nowych inwestycji. Tym istotniejsze będą działania zmierzające do wzmocnienia potencjału endogenicznego regionu, którego ważnym elementem jest sieć ośrodków miejskich [Bogdański 2012, s. 13-14]. Olsztyn jako największe miasto w regionie, ośrodek skupiający znaczną część potencjału gospodarczego, naukowego i społecznego województwa, wciąż w niedostatecznym stopniu pełni funkcję lokomotywy wzrostu dla otaczających go obszarów. Stąd istnieje potrzeba podjęcia działań, które przyczyniłyby się do wzmocnienia procesu dyfuzji procesów rozwojowych ze stolicy województwa do jego regionalnego zaplecza.

Określenie strefy oddziaływania aglomeracji olsztyńskiej w sferze praktyki i polityki rozwoju lokalnego i regionalnego pozwoliłoby również na diagnozę barier i problemów (związanych m.in. ze zjawiskiem urban sprawl) ograniczających lub utrudniających rozwój miasta centralnego i otaczających go ośrodków, zwiększenie zakresu koordynacji polityk rozwojowych poszczególnych jednostek tworzących aglomerację i w konsekwencji zdynamizowanie jej rozwoju społeczno-gospodarczego. W rezultacie może przyczynić się to także do przyspieszenia rozwoju całego regionu warmińsko-mazurskiego.

Prezentowane analizy są badaniami w tym zakresie pionierskimi. Pomimo dużej wagi tego zagadnienia dla praktyki zarządzania miastami i ich rozwojem, dopiero w ostatnich latach można obserwować w naszym kraju zwiększone zainteresowa- 
nie tematyką określenia stref oddziaływania ośrodków miejskich. Były one jednak prowadzone w odniesieniu do największych miast Polski, z pominięciem ośrodków średniej wielkości. Pewnym utrudnieniem był także brak danych statystycznych, które mogłyby być pomocne przy określeniu stopnia powiązań funkcjonalnych Olsztyna z otaczającymi go miejscowościami i jednostkami samorządu terytorialnego.

\section{Aglomeracja miejska i obszary jej oddziaływania - wybrane aspekty teoretyczne}

Termin ,aglomeracja” pochodzi z języka łacińskiego, w którym agglomerare oznacza skupić, koncentrować, scalać odrębne elementy w całość, i w ujęciu funkcjonalnym utrzymał swoje znaczenie. Natomiast w nowszym ujęciu - przedmiotowym, odnosi się do zespołów osadniczych, na które składają się miasta, osiedla oraz inne jednostki osadnicze powiązane ze sobą specjalistycznymi funkcjami i wykazujące się tendencjami do integracji [Brol 2004, s. 20].

Adaptacja pojęć „,aglomeracja”, „konurbacja” czy „obszar metropolitalny” do praktyki badawczej, a także częściowo do sprawozdawczości statystycznej, była rezultatem poszukiwania nowych metod wyznaczania granic obszarów miejskich. Obserwacja procesów społeczno-gospodarczych w miastach i ich otoczeniu pozwoliłaby stwierdzić, że ich przestrzenne oddziaływanie nie ogranicza się jedynie do obszarów domkniętych w granicach administracyjnych miasta. Nowe podejście dawało dogodną perspektywę nie tylko do analizy procesów urbanizacji, ale także do analizy migracji [Korcelli 1981, s. 190]. Innymi słowy, dało podstawę do uchwycenia funkcjonalnych związków miasta $\mathrm{z}$ regionem.

Po raz pierwszy rosnące zainteresowanie problematyką rozwoju, funkcjonowania i delimitacji aglomeracji oraz obszarów ich oddziaływania dało się zauważyć w Polsce w latach 60. XX wieku. Prace podjęte wówczas zaowocowały przyjęciem przez KPZK PAN definicji aglomeracji miejskiej, zgodnie z którą jest nią: „zespół jednostek osadniczych, w których pod wpływem specjalizacji funkcjonalnej poszczególnych jednostek rozwijają się wzajemne współzależności w postaci intensywnych przemieszczeń (przede wszystkim codziennych) osób, towarów, usług i informacji prowadzących do integracji społecznej i gospodarczej" (za: [Gorzelak, Smętkowski 2005, s. 14]). Choć w późniejszej literaturze przedmiotu można znaleźć wiele innych definicji aglomeracji miejskiej, wydaje się, że przytoczona powyżej w sposób najbardziej trafny oddaje istotę tego pojęcia.

Punktem wyjścia dla wzrostu zainteresowania tą tematyką było postawienie przez S. Leszczyńskiego i K. Dziewońskiego przełomowej wówczas tezy, że stosowanie dychotomicznego podziału przestrzeni geograficznej na obszary miejskie i wiejskie jest nieadekwatne do zmieniającej się rzeczywistości społeczno-gospodarczej. Dominującą pozycję w krajowym systemie osadniczym zaczęły bowiem zdobywać aglomeracje, w skład których wchodziły zarówno ośrodki miejskie, jak i wsie. Co więcej, pod względem pełnionych funkcji obszary wiejskie położone wo- 
kół aglomeracji upodobniły się do miast. Przyjęcie tych tez dało także podstawę do przeformułowania kryteriów, za pomocą których dokonywano delimitacji obszarów aglomeracyjnych - w miejsce dotychczas stosowanych kryteriów odnoszących się do sposobu zagospodarowania terenu zaczęto wykorzystywać mierniki odzwierciedlające funkcjonalne powiązania badanych ośrodków [Eberhardt 2002, s. 56].

Uszczegółowiając, można stwierdzić, że aglomeracja miejska jest fragmentem przestrzeni, w której na skutek rosnącej specjalizacji i koncentracji osadnictwa oraz działalności gospodarczej można obserwować większą intensywność tej działalności oraz wyższą dynamikę przebiegu procesów rozwoju społeczno-gospodarczego. W innym, bardziej ogólnym ujęciu aglomeracją jest każda większa jednostka osadnicza wyższego poziomu centralności wraz z obszarem jego oddziaływania. Ponieważ taką strefę ma praktycznie każde miasto, precyzyjna identyfikacja i delimitacja aglomeracji miejskich wymaga zatem odpowiedzi na pytanie, jakimi cechami musi charakteryzować się jej miasto centralne.

W pierwszych badaniach dotyczących aglomeracji wskazywano, że miasto centralne powinno charakteryzować się dostatecznie dużą liczbą mieszkańców, przy czym, w zależności od autora, wielkości te wahały się znacznie [Parysek 2009, s. 34]. To, co jednak jest charakterystyczne dla miasta centralnego aglomeracji, to rodzaj i stopień pełnionych przez nie funkcji. Funkcje te charakteryzują się wyższym stopniem centralności w ujęciu zaproponowanym już przez Christalera [Przygodzki 2007, s. 49]. W ośrodku takim będą dominowały zatem funkcje administracyjne, handlowe, usługowe, kulturalne, oświatowe i naukowe, o znacznym stopniu specjalizacji, obsługujące większy obszar geograficzny.

W ujęciu funkcjonalnym jednostki osadnicze wchodzące w skład aglomeracji miejskiej są hierarchicznie podporządkowane jego miastu centralnemu. W tym kontekście aglomerację miejską można utożsamiać z pojęciem regionu węzłowego. Jednak obszar aglomeracyjny od regionu węzłowego odróżnia przede wszystkim wielkość ośrodka centralnego, większy stopień policentryczności, znaczny stopień zurbanizowania przestrzeni oraz silne powiązania wewnętrzne [Parysek 2009, s. 33]. Widocznym i namacalnym elementem spajającym aglomerację w funkcjonalną całość jest sieć infrastruktury technicznej, ze szczególnie istotną funkcją komunikacji pasażerskiej [Parysek 2009, s. 48]. Pewną rolę w zapewnieniu spójności wewnętrznej aglomeracji odgrywa także dostęp do infrastruktury społecznej, obecność w mieście centralnym (rdzeniu aglomeracji) prestiżowych obiektów (galerii, pasaży) handlowych oraz dużych obiektów handlowych na jej peryferiach [Parysek 2009, s. 49]. Podobnie obecność w strefie oddziaływania aglomeracji terenów zielonych, rekreacyjnych może sprzyjać integracji mieszkańców aglomeracji oraz jej spójności przestrzennej [Parysek 2008, s. 30-31].

Do cech wyróżniających aglomeracje miejskie spośród obszarów zurbanizowanych należą [Brol 2004, s. 20]:

- wysoki poziom zurbanizowania całego zespołu aglomeracyjnego;

- związanie z jednym wielkim miastem lub wieloma miastami; 
- koncentracja funkcji produkcyjnych, a także usługowych;

- złożony system powiązań funkcjonalno-przestrzennych pomiędzy jednostkami osadniczymi tworzącymi aglomerację;

- ciągłość obszaru.

W ostatnich latach coraz częściej można zauważyć tendencję do określania aglomeracji mianem metropolii i odpowiednio obszaru aglomeracyjnego mianem obszaru metropolitalnego. Jest to zapewne wynikiem obserwacji procesów i zmian zachodzących w przebiegu procesów gospodarczych we współczesnym świecie, w wyniku których dominującą pozycję zajmują duże ośrodki miejskie, o specyficznej strukturze produkcji, rozbudowanych funkcjach egzogenicznych, z wysokim potencjałem ekonomicznym, naukowym, innowacyjnym. Ośrodki te określane są mianem metropolii. Stosowanie przytoczonych pojęć zamiennie jest uzasadnione jedynie w przypadku, gdy centrum aglomeracji stanowi ośrodek miejski spełniający kryteria metropolitalności. Stąd nie każda aglomeracja jest metropolią, ale każda metropolia jest aglomeracją [Gorzelak, Smętkowski 2005, s. 13-15].

Przyjmując za podstawę kryterium funkcjonalne, według Smętkowskiego, strefy przestrzennego oddziaływania aglomeracji/metropolii można podzielić na [Smętkowski 2012, s. 2-3]:

- obszar aglomeracyjny - silnie zintegrowany funkcjonalnie obszar, w którym realizowane są różnorodne funkcje o charakterze produkcyjnym, konsumpcyjnym, administracyjnym czy handlowym. Funkcje te mogą być realizowane w różnych fragmentach obszaru aglomeracyjnego, stąd pod tym względem nie jest on jednorodny, ale zawsze charakteryzuje się dużym stopniem integracji, intensywności powiązań. Pewnym odpowiednikiem tego terminu w polskiej literaturze jest pojęcie miejskiego regionu funkcjonalnego. Najważniejszym kryterium używanym do delimitacji miejskiego regionu funkcjonalnego jest przestrzenny zasięg codziennych dojazdów do pracy. Rzadziej wykorzystuje się analizę zakresu powiązań wynikających z przepływu dóbr, kapitału i informacji. Tym, co odróżnia miejski region funkcjonalny od dalszego zaplecza funkcjonalnego miasta, jest fakt, że proces dyfuzji zjawisk i procesów społecznych, ekonomicznych, technologicznych nie ma charakteru hierarchicznego;

- region aglomeracyjny - pojęcie odnosi się do obszaru funkcjonalnie związanego z miastem centralnym i jednocześnie będącego pod jego dominującym wpływem. W przeciwieństwie jednak do obszaru aglomeracyjnego relacje te mają hierarchiczny układ. Granice regionu aglomeracyjnego można wyznaczyć przez analizę dominującego wpływu usług (prasowych, telekomunikacyjnych, finansowych, zarządczych, wyspecjalizowanych usług handlowych i innych). Odpowiednikiem tego terminu w polskiej literaturze jest pojęcie makroregionu funkcjonalnego.

Oprócz powyższych, w literaturze przedmiotu można spotkać jeszcze wiele opracowań i koncepcji określających przestrzenny zakres oddziaływania miasta oraz charakteryzujących wymiary relacji miasta z jego otoczeniem. Ich bardziej szcze- 
gółowy przegląd można znaleźć w pracach Korcellego [1981] oraz Smętkowskiego [2012]. Choć zwracają one uwagę na różne aspekty, to pod wieloma względami są zbieżne z przytoczonym powyżej podziałem. Właśnie ten podział stał się podstawą dla propozycji kryteriów delimitacji olsztyńskiego obszaru aglomeracyjnego.

\section{Koncepcja metodyczna badań}

Problematyka właściwego zdefiniowania kryteriów delimitacji, a następnie zidentyfikowania granic oddziaływania społeczno-gospodarczego miast w przestrzeni geograficznej ma fundamentalne znacznie w badaniach nad aglomeracjami miejskimi. Jednak ze względu na brak ostrości oraz wielowymiarowość samego pojęcia „,aglomeracja miejska" istnieje pewien margines dla subiektywnego doboru miar oraz ich wartości określających zasięg obszaru funkcjonalnego aglomeracji.

W polskiej literaturze z zakresu geografii ekonomicznej oraz gospodarki przestrzennej istnieje wiele opracowań, których celem była delimitacja obszarów wybranych aglomeracji miejskich. Pierwsze powstały na przełomie lat 60. i 70. ubiegłego wieku [Eberhardt 2002, s. 60-61; Smętkowski 2012, s. 8]. Jednak, jak zauważa Czyż, wszystkie podejmowane wówczas badania opierały się na podobnych założeniach [Czyż 2009, s. 18]:

1) definiowaniu aglomeracji miejskich jako głównego ośrodka miejskiego oraz otaczającego go obszaru zurbanizowanego;

2) wydzielaniu kilku stref zaplecza różniących się głównie zaawansowaniem procesów urbanizacji;

3) merytoryczne kryteria delimitacyjne nie różniły się istotnie, a minimalną wielkość ośrodka centralnego ustalano arbitralnie.

Przez kolejnych 30 lat można było obserwować zauważalny spadek zainteresowania tematyką wyznaczania obszarów funkcjonalnych miast. W kolejnych latach nie pojawiły się opracowania o charakterze naukowym, które wnosiły nowe, istotne spostrzeżenia w tej kwestii, co było częściowo uwarunkowane spadkiem zainteresowania ze strony władz krajowych [Eberhardt 2002, s. 62-63]. Ponowny wzrost zainteresowania tą tematyką można obserwować po roku 2000. Do ważniejszych, prowadzonych w tym zakresie prac można zaliczyć badania prowadzone przez Swianiewicza i Klimską [2005], Gorzelaka i Smętkowskiego [2005] oraz Smętkowskiego [2012]. Szczególnie ostatnie opracowanie wnosi pewne istotne spostrzeżenia co do specyfiki funkcjonowania aglomeracji miejskich oraz kryteriów ich delimitacji.

Jak zauważa autor, w miarę transformacji polskiej gospodarki użyteczność wykorzystania niektórych wskaźników służących delimitacji obszarów aglomeracyjnych staje się ograniczona. Dotyczy to przede wszystkim wskaźnika gęstości zaludnienia ludności na obszarze miasta centralnego. W kontekście postępujących procesów „rozlewania się" miast jego wysokie wartości przestają być atrybutem miast centralnych. Dodatkowo możemy obserwować także coraz większą dynamikę zjawisk społeczno-gospodarczych przy jednocześnie występującej znacznej inercji ukształtowanych wcześniej struktur społeczno-gospodarczych [Smętkowski 2012, s. 10]. 
Aglomeracje miejskie i metropolie są obszarami, gdzie można obserwować szczególnie wysoką dynamikę zmian aktywności gospodarczej i społecznej, stąd dla celów delimitacji obszarów funkcjonalnych tych ośrodków należałoby użyć wskaźników obrazujących nie tylko ich stan (poziom), ale także dynamikę.

Aglomeracje miejskie oraz metropolie stanowią regionalne bieguny wzrostu, a te powinny charakteryzować się następującymi cechami [Smętkowski 2012, s. 11]:

1) posiadanie odpowiedniej wielkości;

2) reprezentowanie dynamicznych dziedzin działalności gospodarczej;

3) posiadanie licznych i intensywnych powiązań z innymi dziedzinami działalności społecznej i gospodarczej.

Liczba mieszkańców Olsztyna na koniec 2011 r. wynosiła blisko 176,5 tys., co w skali całego kraju sytuuje ten ośrodek w gronie miast o średniej wielkości. Jednak w województwie warmińsko-mazurskim jest to zdecydowanie największe miasto, stolica regionu, największy i najważniejszy ośrodek administracyjny, gospodarczy, uniwersytecki. Łącznie cały powiat olsztyński zamieszkuje blisko 300 tys. osób, czyli prawie 1/5 ludności całego województwa. Jest to więc obszar o znacznym, w skali całego regionu, potencjale gospodarczym, naukowym, politycznym i spełnia on zarówno ilościowe, jak i jakościowe kryteria charakterystyczne dla obszarów aglomeracyjnych. Otwarte pozostaje jednak pytanie o przestrzenny zasięg egzogenicznych funkcji Olsztyna, które można by określić mianem funkcji aglomeracyjnych.

Przy doborze wskaźników określających granice obszaru aglomeracji olsztyńskiej starano się uwzględnić wszystkie przytoczone aspekty funkcjonowania aglomeracji miejskiej. Zastosowano wskaźniki określające stan najważniejszych cech i zjawisk typowych dla aglomeracji, ale także dynamikę wybranych procesów, zwłaszcza społeczno-ekonomicznych.

Podstawowym kryterium decydującym o zaliczeniu danej jednostki przestrzennej do aglomeracji był wskaźnik dotyczący dziennych przepływów pracowników. Przyjęto, że tylko te jednostki, w których co najmniej 20\% ludności pracującej poza rolnictwem dojeżdża do pracy do ośrodka centralnego - Olsztyna, mogą wchodzić w skład obszaru aglomeracyjnego. Dla celów powyższych analiz posłużono się danymi opracowanymi przez GUS, na podstawie bazy POLTAX. Jest to zbiór danych dotyczących płatników podatku dochodowego, z którego wyodrębniono tych podatników, których miejsce zamieszkania było inne niż miejsce osiągania przychodów i którzy korzystali z prawa zwiększenia kosztów uzyskania przychodu z tytułu dojazdów do pracy. Zestawiając ze sobą miejsca zamieszkania z miejscem uzyskiwania przychodów, uzyskano przybliżone dane dotyczące wahadłowych dziennych przepływów ludności. Jakkolwiek każdą inicjatywę zmierzającą do ustalenia skali oraz kierunków przepływów związanych z zatrudnieniem w Polsce należy uznać za pożądaną, to należy mieć na uwadze, że powyższe badania nie są w stanie oddać w pełni skali oraz zakresu tego zjawiska, chociażby ze względu na znaczne rozmiary „szarej strefy” oraz niedostatki systemu meldunkowego w Polsce. 
Kolejne wskaźniki, które planuje się wykorzystać do delimitacji aglomeracji olsztyńskiej, dotyczą intensywności wykorzystania przestrzeni (kryterium morfologiczne). Założono, że tylko te jednostki, w których liczba izb na $\mathrm{km}^{2}$ była wyższa od trzeciego kwartyla dla gmin miejsko-wiejskich w tym samym województwie i w których gęstość zaludnienia jest również wyższa od trzeciego kwartyla dla gmin miejsko-wiejskich w województwie, charakteryzują się dostatecznie intensywnym sposobem wykorzystania przestrzeni, który jest typowy dla aglomeracji miejskich.

Powyższe wskaźniki mają charakter statyczny i zostaną oszacowane dla roku 2006 ze względu na fakt, że wyniki badań dotyczących przepływów ludności zostały obliczone tylko dla tego roku.

Kolejne wskaźniki mają charakter dynamiczny, co wynika z potrzeby weryfikacji tezy, że obszar aglomeracji miejskiej charakteryzuje się, w stosunku do swego otoczenia, wyższą dynamiką przebiegu zjawisk społeczno-gospodarczych. Przyjęto zatem, że do obszaru aglomeracji olsztyńskiej zaliczone zostaną tylko te jednostki, w których dynamika wzrostu dochodów własnych jednostek samorządu terytorialnego (dochody własne gmin), w przeliczeniu na jednego mieszkańca, była wyższa niż przeciętne tempo ich wzrostu dla wszystkich gmin województwa warmińsko-mazurskiego (jako syntetycznego wskaźnika tempa rozwoju gospodarczego danej jednostki) oraz w których przeciętne tempo wzrostu liczby zarejestrowanych podmiotów gospodarczych, w przeliczeniu na 1000 mieszkańców, było wyższe niż średnia dla całego województwa (jako przybliżonej miary stopnia przedsiębiorczości mieszkańców gminy). W odniesieniu do sfery społecznej, aby dana jednostka mogła być zaliczona do obszaru aglomeracji olsztyńskiej, powinna się charakteryzować nieujemnym saldem migracji.

Wskaźnikiem, który w pewnym sensie może odzwierciedlać stopień powiązań badanej jednostki przestrzennej z miastem centralnym aglomeracji oraz poziom jej rozwoju gospodarczego, jest udział pracujących poza rolnictwem w ogólnej liczbie pracujących. Rozważając strukturę produkcji dużych i średnich miast, należy stwierdzić, że jedną z jej charakterystycznych cech jest relatywnie mały udział produkcji rolniczej, co przekłada się także na względnie małe zatrudnienie w tym sektorze produkcji (w $2006 \mathrm{r}$. w Olszynie w sektorze rolniczym pracowało 0,5\% ogółu zatrudnionych $\left.{ }^{1}\right)$. Zakładając istnienie silnych powiązań gospodarczych miasta centralnego z otaczającym je obszarem, czego przejawem powinna być relatywnie intensywna wymiana dóbr i usług pomiędzy podmiotami położonymi w obszarze aglomeracji miejskiej oraz intensywne dzienne, wahadłowe dojazdy do pracy, należy stwierdzić odzwierciedlenie tego w podobnej strukturze produkcji i zatrudnienia na terenach położonych wokół miasta centralnego, znajdujących się w strefie jego oddziaływania.

${ }^{1}$ Zob.: Województwo warmińsko-mazurskie. Podregiony, powiaty, gminy 2007, Urząd Statystyczny w Olsztynie, Olsztyn 2007. 
Przyjęty zestaw wskaźników wygląda więc następująco:

- W1 - odsetek ludności pracującej poza rolnictwem w badanym roku, która dojeżdża do pracy do ośrodka centralnego, nie może być niższy niż $20 \%$;

- W2 - liczba izb na $\mathrm{km}^{2}$ w 2006 r. powinna być wyższa od trzeciego kwartyla dla gmin miejsko-wiejskich w tym samym województwie;

- W3 - gęstość zaludnienia w 2006 r. powinna być wyższa od trzeciego kwartyla dla gmin miejsko-wiejskich w tym samym województwie;

- W4 - w latach 2006-2009 przeciętne roczne tempo wzrostu dochodów własnych gmin w przeliczeniu na 1 mieszkańca było wyższe niż średnia dla całego województwa warmińsko-mazurskiego;

- W5 - w latach 2006-2009 przeciętne roczne tempo wzrostu podmiotów gospodarczych na 1000 mieszkańców było wyższe niż średnia dla całego województwa;

- W6 - badana jednostka w latach 2006-2009 musi się charakteryzować nieujemnym saldem migracji;

- W7 - odsetek pracujących poza rolnictwem w ogólnej liczbie pracujących musi przekraczać $80 \%$.

W przypadku wskaźnika W4 posłużenie się wartością dochodów własnych gmin w przeliczeniu na 1 mieszkańca, jako miarą tempa rozwoju gospodarczego, wynikało z braku dostępności danych statystycznych dotyczących m.in. kształtowania się wartość PKB w ujęciu gminnym. Oznaczało to konieczność poszukiwania innych danych publikowanych na poziomie gminnym, które byłyby pomocne przy określeniu poziomu i tempa rozwoju gospodarczego gmin. Przy doborze tego kryterium kierowano się modelem rozwoju gospodarczego układu lokalnego stworzonego przez Smętkowskiego. Jak zauważa ten autor, im wyższym tempem rozwoju gospodarczego będzie charakteryzowała się dana jednostka, tym szybciej będą rosły jej dochody własne [Smętkowski 2012, s. 9-10].

Przyjęto przy tym zasadę, że aby daną jednostkę zaliczyć do aglomeracji olsztyńskiej, musi ona spełnić kryterium W1 oraz przynajmniej trzy z pozostałych sześciu kryteriów.

Jeżeli chodzi o przedmiot badań, to będą nimi objęte gminy województwa warmińsko-mazurskiego.

\section{Granice aglomeracji olsztyńskiej - wyniki przeprowadzonych analiz}

Przy delimitacji aglomeracji olsztyńskiej przyjęto zasadę, że jej zasięg powinien ograniczać się do obszaru położonego w promieniu $50 \mathrm{~km}$ (jest to dystans, który jest możliwy do pokonania samochodem oraz środkami komunikacji publicznej w czasie zbliżonym do godziny) od miasta centralnego - Olsztyna². Odległość tę okre-

${ }^{2}$ Przyjęcie odległości $50 \mathrm{~km}$ jako granicznej strefy oddziaływania i powiązań w ramach aglomeracji wynika także z faktu, że - jak zauważa Wilkin - największe zmiany w sposobie wykorzystania przestrzeni, zagospodarowania terenu oraz pełnionych funkcji w ostatnich latach można obserwować na obszarach położonych w 50-kilometrowym pasie wokół miast [Wilkin 2005, s. 42]. 
ślono, mierząc długość najkrótszego połączenia drogowego pomiędzy ośrodkiem będącym siedzibą danej gminy a centrum Olsztyna. W ten sposób analizą objęto także te gminy, które w całości nie mieszczą się w tym promieniu. Ostatecznie w badaniach uwzględniono 25 jednostek - były to wszystkie gminy leżące w powiecie olsztyńskim, cztery gminy położone w powiecie lidzbarskim (Lidzbark Warmiński, Kiwity, Lubomino, Orneta), cztery w ostródzkim (Ostróda, Miłakowo, Morąg, Łukta), cztery w szczycieńskim (Szczytno, Dźwierzuty, Jedwabno, Pasym) oraz jedną gminę z powiatu mrągowskiego (Sorkwity).

W pierwszej kolejności określono intensywność powiązań funkcjonalnych na podstawie analizy danych dotyczących dziennych wahadłowych dojazdów do pracy. W tabeli 1 zaprezentowano dane dotyczące udziału osób dojeżdżających do pracy do Olsztyna w ogólnej liczbie pracujących poza rolnictwem na terenie gminy (pogrubioną czcionką zaznaczono te gminy, które spełniły powyższe kryterium).

Tabela 1. Udział osób dojeżdżających do pracy do Olsztyna w ogólnej liczbie pracujących poza rolnictwem w gminie w $2006 \mathrm{r}$.

\begin{tabular}{|l|c|}
\hline \multicolumn{1}{|c|}{ Gmina } & $\begin{array}{c}\text { Odsetek pracujących poza rolnictwem dojeżdżających do pracy } \\
\text { do miasta centralnego }\end{array}$ \\
\hline Barczewo & $\mathbf{4 1 , 6}$ \\
\hline Biskupiec & 12,9 \\
\hline Dobre Miasto & $\mathbf{2 0 , 0}$ \\
\hline Dywity & $\mathbf{5 2 , 5}$ \\
\hline Gietrzwałd & $\mathbf{4 9 , 5}$ \\
\hline Jeziorany & $\mathbf{2 9 , 5}$ \\
\hline Jonkowo & $\mathbf{3 5 , 8}$ \\
\hline Kolno & $\mathbf{2 4 , 2}$ \\
\hline Olsztynek & 12,5 \\
\hline Purda & $\mathbf{1 5 6 , 7}$ \\
\hline Stawiguda & $\mathbf{4 9 , 2}$ \\
\hline Świątki & $\mathbf{5 4 , 3}$ \\
\hline Lidzbark Warmiński & 5,5 \\
\hline Kiwity & $\mathbf{3 5 , 9}$ \\
\hline Lubomino & $\mathbf{3 8 , 6}$ \\
\hline Orneta & 8,5 \\
\hline Ostróda & 5,4 \\
\hline Miłakowo & 8,7 \\
\hline Morąg & 7,2 \\
\hline Łukta & $\mathbf{2 6 , 1}$ \\
\hline Szczytno & 5,9 \\
\hline Dźwierzuty & $\mathbf{4 6 , 5}$ \\
\hline Jedwabno & 13,7 \\
\hline Pasym & $\mathbf{4 2 , 4}$ \\
\hline Sorkwity & 11,5 \\
\hline Źt & \\
\hline
\end{tabular}

Źródło: Bank Danych Lokalnych GUS: http://www.stat.gov.pl/bdl/app/strona.html?p_name=indeks, 9.05.2012 r. 
Z zaprezentowanych danych wynika, że siła i zakres powiązań funkcjonalnych Olsztyna i położonych wokół niego gmin tylko do pewnego stopnia uwarunkowane były dostępnością komunikacyjną. Relatywnie największym odsetkiem dojeżdżających do pracy do Olsztyna charakteryzowały gminy leżące wokół tego miasta oraz gminy sąsiadujące z nimi, z których względnie szybko można dojechać do miasta centralnego. Interesujące w tym kontekście są takie gminy, jak: Biskupiec, Olsztynek czy Ostróda. Dostępność komunikacyjna Olsztyna dla mieszkańców tych gmin jest również wysoka dzięki dobrym połączeniom komunikacyjnym (DK16 oraz połączenia autobusowe i kolejowe w przypadku Ostródy i Biskupca) i/lub dzięki relatywnie niewielkiej odległości od Olsztyna (Olsztynek). Mimo to odsetek dojeżdżających do pracy do miasta centralnego jest tam niższy niż w gminach gorzej skomunikowanych z Olsztynem (np. Dźwierzuty, Świątki, Kiwity, Lubomino). Wydaje się, że w tym przypadku jest to spowodowane relatywnie dużą, biorąc pod uwagę charakterystykę sieci osadniczej całego województwa, liczbą mieszkańców miast będących siedzibami wspomnianych trzech gmin. Rynek pracy tych ośrodków miejskich jest więc prawdopodobnie na tyle duży, że zaspokaja potrzeby nie tylko ich mieszkańców, ale także ludności pozostałych obszarów gminy.

Ciekawym przypadkiem w tym zestawieniu jest również gmina Purda. Jest to jedyna gmina, w której liczba pracujących poza rolnictwem na terenie tej jednostki samorządowej jest mniejsza niż liczba dojeżdżających do pracy do innych ośrodków, w tym przede wszystkim do Olsztyna. Prawdopodobnie jest to konsekwencją niewielkiej liczby mieszkańców gminy i tym samym - niewielkiego potencjału gospodarczego. Niemniej jednak oznacza to także, z punktu widzenia gospodarstw domowych, znaczną zależność od sytuacji na rynku pracy innych gmin, głównie Olsztyna.

Po odrzuceniu jednostek niespełniających pierwszego kryterium do dalszego badania przyjęto 15 gmin. W tabeli 2 przedstawiono dane odnoszące się do kolejnych kryteriów delimitacji aglomeracji olsztyńskiej (w tabeli kolorem szarym zaznaczono wartości badanych zmiennych spełniające opisane wcześniej kryteria).

Najwięcej gmin - 14, spełniło kryterium dotyczące odsetka ludności pozarolniczej w ogólnej liczbie pracujących (W7). Kształtowanie się tego wskaźnika wydaje się potwierdzać istnienie silnych powiązań funkcjonalnych pomiędzy tymi gminami a miastem centralnym aglomeracji oraz pozytywne oddziaływanie Olsztyna na gospodarki badanych jednostek. Potwierdza to również analiza wartości wskaźników W4 i W5, które także odnoszą się do gospodarczego wymiaru relacji ośrodków położonych w granicach aglomeracji olsztyńskiej. W przypadku każdego z tych wskaźników 12 na 15 analizowanych gmin charakteryzowało się dostatecznie wysokimi jego wartościami, aby móc zaliczyć je do obszaru badanej aglomeracji miejskiej.

W przypadku aglomeracji olsztyńskiej stosunkowo najsłabiej zauważalny był aspekt związany z charakterem i intensywnością wykorzystania przestrzeni (wskaźniki W2 i W3). Zaledwie dwie gminy spełniają kryterium intensywności zabudowy oraz gęstości zaludnienia. Były to Dobre Miasto i Dywity. Przyczyną tego może 
Tabela 2. Charakterystyka wybranych obszarów funkcjonowania niektórych gmin województwa warmińsko-mazurskiego

\begin{tabular}{|l|c|c|c|c|c|c|}
\hline \multicolumn{1}{|c|}{ Gmina } & W2 & W3 & W4 & W5 & W6 & W7 \\
\hline $\begin{array}{l}\text { Graniczna } \\
\text { wartość } \\
\text { przyjętego } \\
\text { kryterium }\end{array}$ & 63,87 & 52,43 & 8,37 & 1,05 & $\begin{array}{c}\text { saldo } \\
\text { migracji }>0\end{array}$ & 80 \\
\hline Barczewo & 59,05 & 51,51 & 11,20 & 4,00 & 360 & 92,34 \\
\hline Dywity & 78,93 & 57,58 & 6,02 & 3,38 & 893 & 93,46 \\
\hline Gietrzwałd & 39,15 & 31,16 & 12,90 & 3,15 & 298 & 82,59 \\
\hline Jonkowo & 41,94 & 33,98 & 11,13 & 2,87 & 679 & 97,70 \\
\hline Purda & 26,69 & 23,18 & 13,30 & 1,85 & 307 & 79,80 \\
\hline Stawiguda & 32,53 & 23,05 & $-1,50$ & 3,59 & 944 & 91,70 \\
\hline Dobre Miasto & 70,46 & 61,43 & 17,71 & 3,10 & -252 & 97,85 \\
\hline Jeziorany & 39,83 & 39,11 & 11,52 & 2,32 & -180 & 90,60 \\
\hline Kolno & 22,10 & 19,45 & 6,04 & 3,84 & -118 & 88,31 \\
\hline Świątki & 26,59 & 25,93 & 11,06 & 2,05 & -85 & 95,88 \\
\hline Kiwity & 26,42 & 23,86 & 13,41 & $-1,17$ & -74 & 87,97 \\
\hline Lubomino & 26,14 & 25,21 & 13,07 & 0,68 & -68 & 85,65 \\
\hline Łukta & 26,86 & 24,21 & 10,40 & 1,77 & -51 & 96,43 \\
\hline Dźwierzuty & 28,20 & 25,79 & 9,76 & 2,23 & -245 & 81,43 \\
\hline Pasym & 42,35 & 34,55 & 15,71 & $-0,06$ & 13 & 93,49 \\
\hline
\end{tabular}

Źródło: obliczenia własne na podstawie: GUS Bank Danych Lokalnych (http://www.stat.gov.pl/bdl, 09.05.2012 r.) oraz US w Olsztynie, Województwo warmińsko-mazurskie. Podregiony, powiaty, gminy 2007.

być fakt, że z jednej strony województwo warmińsko-mazurskie należy do najsłabiej zaludnionych obszarów Polski, a z drugiej, co wydaje się bardziej prawdopodobne, że aglomeracja olsztyńska znajduje się dopiero na etapie wykształcania się i budowania własnych struktur przestrzennych. Pewnym potwierdzeniem ostatniej tezy są dane dotyczące salda migracji. Jedynymi gminami, które w badanym okresie charakteryzowały się dodatnim saldem migracji wewnętrznych i zewnętrznych, były gminy położone wokół Olsztyna. Jednocześnie liczba mieszkańców samego Olsztyna w badanym okresie wzrosła o blisko 1100 osób, co oznacza, że wzrost liczby mieszkańców gmin ościennych nie wynikał jedynie z procesu dezurbanizacji miasta centralnego. Świadczy to o stopniowej koncentracji działalności gospodarczej i społecznej wokół stolicy regionu, czego konsekwencją będzie zapewne także zwiększenie intensywności zabudowy przestrzeni wokół niego.

Uwzględniając wszystkie powyższe rozważania, można przyjąć, że w skład aglomeracji olsztyńskiej wchodzi, oprócz samego Olsztyna, 12 gmin. 9 z nich należy do powiatu olsztyńskiego (Barczewo, Dobre Miasto, Dywity, Gietrzwałd, Jeziorany, 
Jonkowo, Purda, Stawiguda, Świątki), dwie do powiatu szczycieńskiego (Dźwierzuty, Pasym) oraz jedna do powiatu ostródzkiego (Łukta). Ich rozmieszczenie zaprezentowano na rys. 1.

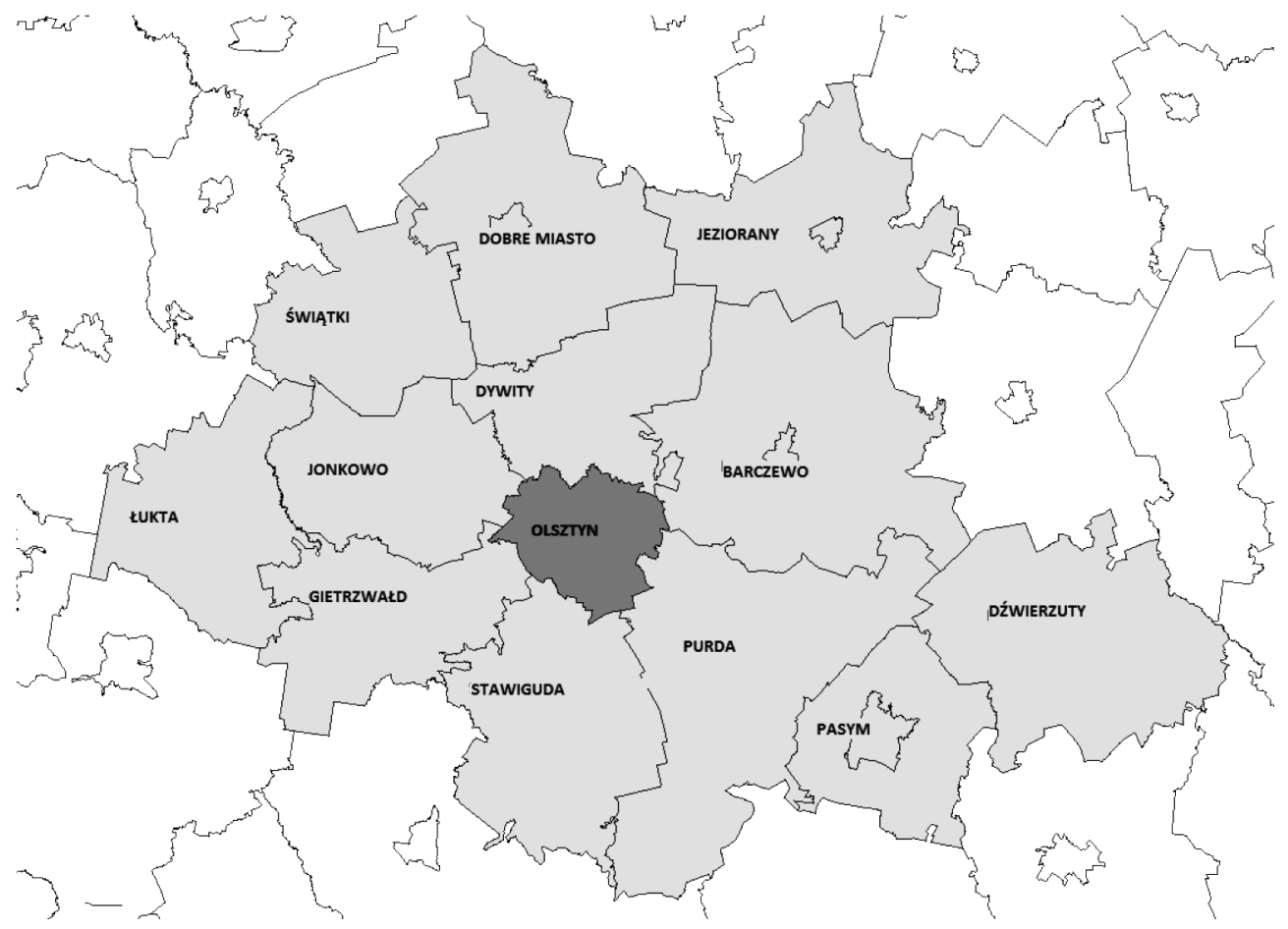

Rys. 1. Obszar aglomeracji olsztyńskiej.

Źródło: opracowanie własne.

Obszar aglomeracji olsztyńskiej w tak zakreślonych granicach zamieszkiwało na koniec 2010 r., według danych GUS, 268684 osób, co stanowiło 18,8\% ludności całego województwa. Powierzchnia aglomeracji wynosi z kolei $2682 \mathrm{~km}^{2}$, czyli $11,1 \%$ powierzchni województwa. Na terenie aglomeracji swoją siedzibę mają najwięksi, najważniejsi w regionie pracodawcy (Uniwersytet Warmińsko-Mazurski, Michelin, Indykpol), instytucje rządowe i samorządowe, uczelnie wyższe (w tym przede wszystkim UWM oraz trzy uczelnie prywatne - Olsztyńska Wyższa Szkoła Informatyki i Zarządzania im. prof. T. Kotarbińskiego, Wyższa Szkoła Informatyki i Ekonomii Towarzystwa Wiedzy Powszechnej w Olsztynie oraz Olsztyńska Szkoła Wyższa im. J. Rusieckiego). Ponadto w Olsztynie zlokalizowane są ważne instytucje kulturalne, gospodarcze (tu znajduje się m.in. siedziba Warmińsko-Mazurskiej Specjalnej Strefy Ekonomicznej oraz Warmińsko-Mazurskiej Agencji Rozwoju Regionalnego), a także placówki opieki zdrowotnej. W strukturze produkcyjnej aglomeracji domi- 
nuje przemysł spożywczy, maszynowy, meblarski oraz oponiarski. Ważną branżą, ze względu na położenie oraz walory krajobrazowe, pozostaje także turystyka.

Poza Olsztynem do najważniejszych ośrodków aglomeracji olsztyńskiej można zaliczyć miasta Barczewo i Dobre Miasto. Ich wielkość mierzona liczbą mieszkańców jest jednak zdecydowanie mniejsza niż miasta centralnego. Również w innych aspektach potencjał społeczny i gospodarczy tych i pozostałych jednostek tworzących aglomerację jest dużo mniejszy od potencjału Olsztyna. Stąd aglomerację olsztyńską można zaliczyć do aglomeracji monocentrycznych, o znacznym stopniu dominacji miasta centralnego. Należy też podkreślić, że o ile w przypadku kryterium powiązań funkcjonalnych oraz dynamiki przebiegu procesów społeczno-gospodarczych można mówić o dość wyrazistych powiązaniach typowych dla aglomeracji miejskich, o tyle względnie słabo zauważalne aspekty związane z wykorzystaniem przestrzeni każą zaliczyć obszar aglomeracji olsztyńskiej do aglomeracji dopiero wyłaniających, kształtujących się.

\section{Podsumowanie i wnioski}

Miasta i aglomeracje miejskie stanowią ważny element systemu przestrzenno-gospodarczego. Można się jednocześnie spodziewać, że ich znaczenie w kształtowaniu potencjału endogennego jednostek przestrzennych będzie rosło. Określenie znaczenia aglomeracji miejskich dla gospodarek regionalnych i krajowych wymaga jednak wcześniejszego wyznaczenia przestrzennego zasięgu ich oddziaływania. Delimitacja tych obszarów jest ważnym zagadnieniem zarówno z teoretycznego, jak i z praktycznego punktu widzenia. W literaturze przedmiotu zwykle wyróżnia się dwie strefy przestrzennego wpływu aglomeracji miejskich - obszar aglomeracji oraz region aglomeracyjny. Pierwszy z nich obejmuje mniejszy pod względem powierzchni obszar, ale charakteryzujący się znacznie silniejszymi powiązaniami funkcjonalnymi miasta centralnego aglomeracji z otaczającymi go jednostkami. Miarą tych powiązań jest m.in. intensywność i zasięg dziennych dojazdów do pracy oraz dynamika zmian zachodzących w sferze społeczno-gospodarczej.

Celem prezentowanych analiz była delimitacja obszaru aglomeracyjnego Olsztyna. Wykorzystano do tego kryteria i wskaźniki oddające stan oraz dynamikę powiązań funkcjonalnych Olsztyna z otaczającymi go gminami, jak również dynamikę procesów społeczno-gospodarczych. Istotnym ograniczeniem był jednak brak danych odzwierciedlających stopień powiązań funkcjonalnych jednostek tworzących aglomerację, a wynikających z przepływu dóbr, usług i informacji oraz oddających tempo zmian ich poziomu rozwoju gospodarczego.

Z przeprowadzonych analiz wynika, że w skład obszaru aglomeracji olsztyńskiej wchodzi większość gmin powiatu olsztyńskiego (z wyjątkiem Kolna, Biskupca i Olsztynka), dwie gminy powiatu szczycieńskiego (Dźwierzuty i Pasym) oraz jedna gmina powiatu ostródzkiego (Łukta). Obszar ten skupia znaczną cześć potencjału ludnościowego, gospodarczego, naukowego i społecznego województwa. 
W badanym okresie można było także zaobserwować stałe zwiększanie się liczby mieszkańców obszaru aglomeracji (zarówno miasta centralnego, jak i jednostek go otaczających), co pozwala przypuszczać, że znaczenie aglomeracji olsztyńskiej w kształtowaniu poziomu oraz dynamiki rozwoju społeczno-gospodarczego województwa warmińsko-mazurskiego będzie wciąż rosło.

W sferze praktycznej, biorąc pod uwagę przestrzenny zasięg aglomeracji olsztyńskiej, można zauważyć, że istotną rolę w kształtowaniu działań zmierzających do formalnego utworzenia związku gmin tworzących aglomerację, a także w koordynacji jej przyszłych projektów, mógłby odegrać starosta powiatu olsztyńskiego oraz prezydent Olsztyna. To z kolei pozwoliłoby na usprawnienie procesu zarządzania jednostkami tworzącymi aglomerację, zoptymalizowanie przestrzennego rozmieszczenia pełnionych na jej obszarze funkcji, zwiększenie atrakcyjności inwestycyjnej, a w konsekwencji na zdynamizowanie jej rozwoju i podniesienie jakości życia mieszkańców.

\section{Literatura}

Bogdański M., Economic potential of polish cities - a regional approach, Bulletin of Geography. Socio-economic series 2012, 17/2012.

Brol R., Miasto - społeczeństwo, gospodarka, przestrzeń, [w:] Ekonomika zarzadzania miastem, red. R. Brol, Wydawnictwo Akademii Ekonomicznej im. Oskara Langego we Wrocławiu, Wrocław 2004.

Czyż T., Koncepcja aglomeracji miejskiej i obszaru metropolitalnego w polskiej geografii miast, [w:] Aglomeracje miejskie w Polsce na przetomie XX i XXI wieku. Problemy rozwoju przeksztatceń strukturalnych i funkcjonowania, red. W. Maik, Wydawnictwo Wyższej Szkoły Gospodarki w Bydgoszczy, Bydgoszcz 2009.

Eberhardt P., Studia nad problematyka delimitacji aglomeracji miejskich w Polsce, [w:] Warszawa jako przedmiot badań w geografii społeczno-ekonomicznej, Prace Geograficzne nr 184, red. G. Węcławowicz, PAN Instytut Geografii i Przestrzennego Zagospodarowania im. S. Leszczyńskiego, Warszawa 2002.

Gorzelak G., Smętkowski M., Metropolia i jej region w gospodarce informacyjnej, Wydawnictwo Naukowe SCHOLAR, Warszawa 2005.

Korcelli P., Regiony miejskie w systemie osadniczym Polski, [w:] Studia nad migracjami i przemianami systemu osadniczego w Polsce, Prace Geograficzne nr 140, red. K. Dziewoński i P. Korcelli, PAN Instytut Geografii i Przestrzennego Zagospodarowania, Warszawa 1981.

Parysek J.J., Aglomeracje miejskie w Polsce oraz problemy ich funkcjonowania i rozwoju, 2008, www. rr.amu.edu.pl/files/RR_05_04.pdf, data dostępu: 09.03.2012.

Parysek J.J., Aglomeracje miejskie: struktura i funkcjonowanie, [w:] Aglomeracje miejskie w Polsce na przełomie XX i XXI wieku. Problemy rozwoju przeksztatceń strukturalnych i funkcjonowania, red. W. Maik, Wydawnictwo Wyższej Szkoły Gospodarki w Bydgoszczy, Bydgoszcz 2009.

Przygodzki Z., Region i klasyczne teorie jego rozwoju, [w:] Region i jego rozwój w warunkach globalizacji, red. J. Chądzyński. A. Nowakowska i Z. Przygodzki, Wydawnictwa Fachowe CeDeWu.pl, Warszawa 2007.

Smętkowski M., Delimitacja obszarów metropolitalnych w Polsce - nowe spojrzenie, https://www.mrr. gov.pl/rozwoj_regionalny/poziom_krajowy/polska_polityka_przestrzenna/zespol_realizacyjny_ KPZK/Documents/535dfcf91f934378972bdbda34e64fceDelimitacjaobszarwmetropolitalnychwPolscenowespojr.pdf, data dostępu 05.03.2012 r. 
Swianiewicz P., Klimska U., Społeczne i polityczne zróżnicowanie aglomeracji w Polsce - waniliowe centrum, mozaika przedmieść, Prace i Studia Geograficzne 2005, tom 35/2005.

Wilkin J., Lepszy świat - polska wieś za 25 lat, [w:] Polska wieś 2025. Wizja rozwoju, red. J. Wilkin, Fundusz Współpracy, Biuro Programów Wiejskich, Warszawa 2005.

Województwo warmińsko-mazurskie. Podregiony, powiaty, gminy 2007, Urząd Statystyczny w Olsztynie, Olsztyn 2008.

\section{DELIMITATION OF A FUNCTIONAL AREA OF OLSZTYN AGGLOMERATION}

Summary: Cities and urban agglomerations shape the process of economic development in a significant way, both in national and regional scale,. The desire to improve the level and dynamics of economic development of an agglomeration and surrounding areas requires a coordination of actions undertaken by local governments of units forming an agglomeration. This, in turn, raises an important issue of determining the spatial extent of their impact.

The aim of the study is to delimitate the boundaries of functional area of Olsztyn agglomeration. Agglomeration area is a highly integrated functional area where various functions are realized like, for example, manufacturing, consumption, administrative or commercial. These functions are realized in different parts of an agglomeration area, so in that respect it is not uniform, but there is always a high degree of integration and an intensity of relationships. Most often used, but not the only one, criterion for the delimitation of functional urban region is the spatial extent of daily commuting.

The factors used to delimitate the functional area of Olsztyn agglomeration relate to morphological criteria (that is associated with the degree, intensity of use of space), the functional criterion (reflecting the degree of relationship between the center city and surrounding area) and a criterion of the dynamics of socio-economic processes taking place in the urban area (they refer primarily to the dynamics of migration processes and to the economic development of the surveyed units). One of the characteristic features of urban agglomerations is, in fact, greater intensity and variability of changes taking place in its functioning.

The analyzes lead to the conclusion that the functional area of Olsztyn agglomeration consists of 12 municipalities (except the city of Olsztyn) - nine of them belong to the Olsztyn poviat (Barczewo, Dobre Miasto, Dywity, Gietrzwałd, Jeziorany, Jonkowo, Purda, Stawiguda, Świątki), two to the Szczytno poviat (Dźwierzuty, Pasym) and one to the Ostróda poviat (Lukta).

The functional area of Olsztyn agglomeration at the end of 2010 consisted of 268684 people, representing $18.8 \%$ of the population of Warmińsko-Mazurskie Voivodship. The size of the area is, in turn, $2682 \mathrm{~km}^{2}$, which makes $11.1 \%$ of the voivodship. The agglomeration is home to the largest and most important in Warmia and Mazury region employers, government agencies and local governments, colleges and universities. In Olsztyn there are also located important for the whole region cultural and economic institutions as well as health care facilities. The production structure is dominated by the food industry, machinery, furniture and tire production. Tourism is also an important industry, because of its location and the landscape.

One can also notice, that in the case of the criterion of functional relationships and the dynamics of the socio-economic processes, there are quite visible and strong relationships shaping Olsztyn agglomeration. In the same time, relatively little noticeable aspects relating to the use of space lead to a conclusion that Olsztyn agglomeration is at the stage of its emerging.

Keywords: urban agglomeration, functional area, Olsztyn. 